\title{
THE CASTING PROCESS AND HIGH TEMPERATURE OXIDATION RESISTANCE OF HIGH CHROMIUM CAST IRON GRATE BAR
}

\author{
Chen Zhiru ${ }^{1}$ - Xu Lei ${ }^{1 *}$ - Zhao Linwei ${ }^{2}$ - Wang Youchao ${ }^{1}$ - Li Changyun ${ }^{1}$ - Mi Guofa ${ }^{1}$
}

${ }^{1}$ The School of Material Science and Engineering, Henan Polytechnic University, Jiaozuo 454000 China;

${ }^{2}$ Zhongyuan Special Steel Co., LTD, Jiyuan 454150, China

\begin{tabular}{l} 
ARTICLE INFO \\
\hline Article history: \\
Received: 29.06 .2016$. \\
Received in revised form: 03.10.2016. \\
Accepted: 18.10 .2016$. \\
\hline Keywords: \\
High chromium cast iron \\
Grate bar \\
Oxidation resistance \\
Oxide films \\
\hline DOI: http://doi.org/10.30765/er.39.1.4
\end{tabular}

\section{Introduction}

A grate bar is an important part of sintering machine. When used, it usually has to bear very complex working conditions like strong impact force, high temperature and severe wear, which make it easier to get damaged [1-3]. In the past, the grate bar was widely manufactured by common gray cast iron, which was found to have many quality problems such as poor high temperature oxidization resistance, short service life, and high consumption, etc. In order to improve the quality, a lot of research work has been done on the grate bar materials. Many kinds of cast iron have been developed, such as silicon nodular iron, high chromium cast iron, and multi-elementally alloyed high chromium cast iron [4]. Among the irons, high chromium cast iron is considered to be the most excellent wear resistant and high temperature oxidation resistance material [5]. For the high content of chromium, $\mathrm{Cr}_{2} \mathrm{O}_{3}$ membrane will be formed on the surface, which can help to prevent or delay the oxidation. Therefore, high chromium cast iron grate bars usually present

\begin{abstract}
:
The solidification process of a high chromium cast iron grate bar used for sinter machine was simulated, and high temperature oxidation resistance was also investigated. The simulation result shows that sequence solidification can be achieved and no shrinkage cavity and porosity were observed. Based on the analysis of the microstructure, it could be known that the grate bar was well protected by the $\mathrm{Fe}_{3} \mathrm{O}_{4}, \mathrm{Fe}_{2} \mathrm{O}_{3}$ and $\mathrm{Cr}_{2} \mathrm{O}_{3}$ oxide films at temperatures lower than $800^{\circ} \mathrm{C}$.
\end{abstract}

good thermal stability and oxidation resistance [6]. Ramírez-Ramírez et al. [7] did investigation on high temperature oxidation behavior of high-chromium white cast iron in atmospheres that include dry air and a mixture of dry air and water vapor. They pointed out that the presence of water vapor and the chromium content has an obvious effect on oxidation rate by a mechanism that involved chromium depletion of oxide as a result of hydroxide formation. Efremenko et al. [8] studied the oxidation and decarburization behavior of 14.55 wt pct Cr-cast iron at $1000^{\circ} \mathrm{C}$ to $1150^{\circ} \mathrm{C}$ in a dry atmosphere, and decarburization phenomenon appeared with the form of secondary and eutectic carbide dissolution accompanying oxidizing heating. Zhang et al. [9] deemed that the oxide type in highchromium cast iron depends on chromium content, and best oxidation resistance can be obtained with chromium content of $15 \mathrm{wt} . \%$.

A kind of high chromium cast iron was designed and used for a grate bar. The grate bar was manufactured by lost foam casting, because it can promote surface smoothness and reduce subsequent 
machining. To prolong the working life of the bar, casting process was simulated to eliminate the defects using View-cast software, and effect factors of high temperature oxidation were also discussed.

\section{Numerical simulation of casting and solidification}

\subsection{The chemical composition design}

Chromium is the main alloy element, which forms $\mathrm{Cr}_{2} \mathrm{O}_{3}$ membrane on the surface at high temperature to improve the heat and oxidation resistance of the casting. It is also worthwhile to mention that the ratio of $\mathrm{Cr} / \mathrm{C}$ has an effect on the type of carbide. When the content of $\mathrm{Cr}$ is higher than $11 \%$ and rate of $\mathrm{Cr} / \mathrm{C}$ is higher than $3.5 \%, \mathrm{M}_{7} \mathrm{C}_{3}$ carbide forms in the high chromium iron [10]. The hardness of $\mathrm{M}_{7} \mathrm{C}_{3}$ carbide is as high as $1300 \mathrm{HV}-1800 \mathrm{HV}$, which is useful for improving strength and wear resistance of the iron. Therefore, appropriate content of $\mathrm{Cr}$ and ration of $\mathrm{Cr} / \mathrm{C}$ are expected to get more $\mathrm{M}_{7} \mathrm{C}_{3}$ carbide.

The designed chemical composition of high chromium iron used for the grate bar is shown in Table 1.

Table 1. The designed chemical composition of high chromium iron

\begin{tabular}{|c|c|c|c|c|c|c|}
\hline Element & $\mathrm{C}$ & $\mathrm{Cr}$ & $\mathrm{Si}$ & $\mathrm{Mn}$ & $\mathrm{P}$ & $\mathrm{S}$ \\
\hline $\begin{array}{c}\text { Content } \\
\text { (wt.\%) }\end{array}$ & $\begin{array}{c}1.6- \\
2.4\end{array}$ & $15-18$ & $\begin{array}{c}1.5- \\
2.2\end{array}$ & $\leq 1.0$ & $\leq 0.1$ & $\leq 0.05$ \\
\hline
\end{tabular}

\subsection{Casting process design of the grate bar}

Grate bar is a small and simple-structure casting. It weighs about $3.7 \mathrm{Kg}$ with the average thickness of about $15 \mathrm{~mm}$. Considering the requirement of batch production, high dimension accuracy, high quality and integrated performance, lost foam casting was used to take place of the traditional sand casting [11].

In order to improve the production efficiency, threelayer modeling of castings was adopted for this case. The castings were connected with the ingratesand six ingrates with the section diameter of $40 \mathrm{~mm}$ were settled. The gating system is shown in Fig. 1. 42 castings are arranged evenly on the six ingrates. The size of the sprue and ingrate are $40 \mathrm{~mm} \times 40 \mathrm{~mm}$ and $\varphi 40 \mathrm{~mm}$. The pouring temperature is controlled to be $1570^{\circ} \mathrm{C}$.

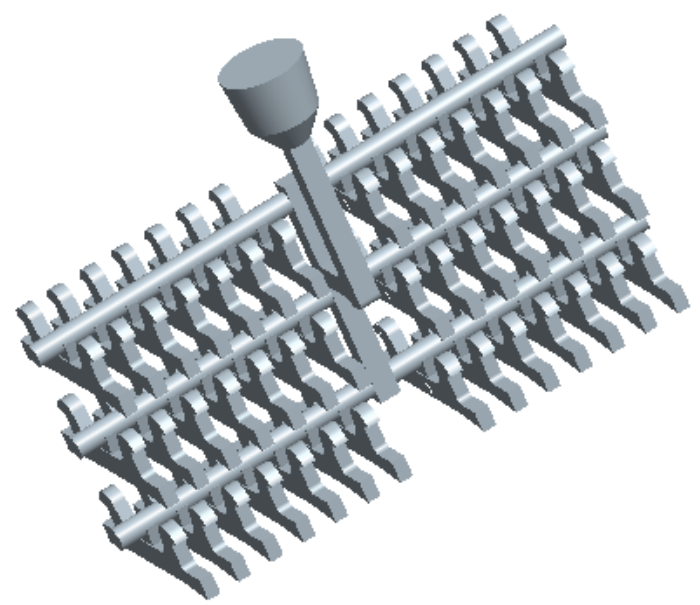

Figure 1. Three-dimensional figure of the Grating system.

\subsection{Simulation of casting and solidification of the bar}

View Cast is useful software that is effective to simulate the solidification temperature field, solidus fraction, mould-filling time and velocity field during the filling process. Usually, it is also used to predict casting defects and optimize gating system $[12,13]$. Before simulation, three-dimensional model is generated by Pro/E and is exported in *stl file format. The casting and gating system are divided into 2 million grids. The initial and gating temperatures are set at $25^{\circ} \mathrm{C}$ and $1570^{\circ} \mathrm{C}$ respectively, and negative pressure is $-400 \mathrm{KPa}$. The simulation results of mould-filling and solidification are represented respectively in Fig. 2 and Fig. 3.

Figure 2 presents the six stages of the mould-filling. The diagram demonstrated that the gating process is smooth and there is not turbulence in the pouring process.

As shown in Fig. 3, when the solidification time was 135 seconds, both sides of the casting began to solidify. After 335 seconds, the solidification area expanded from lateral to internal gradually. As the size of the casting is small with very thin thickness, the solidification rate was very fast, and complete solidification in the castings was obtained after $\mathbf{4 1 5}$ seconds. However, there was still incomplete solidification in the middlesprue, ingrate and runner, which led to more easily feeding. 


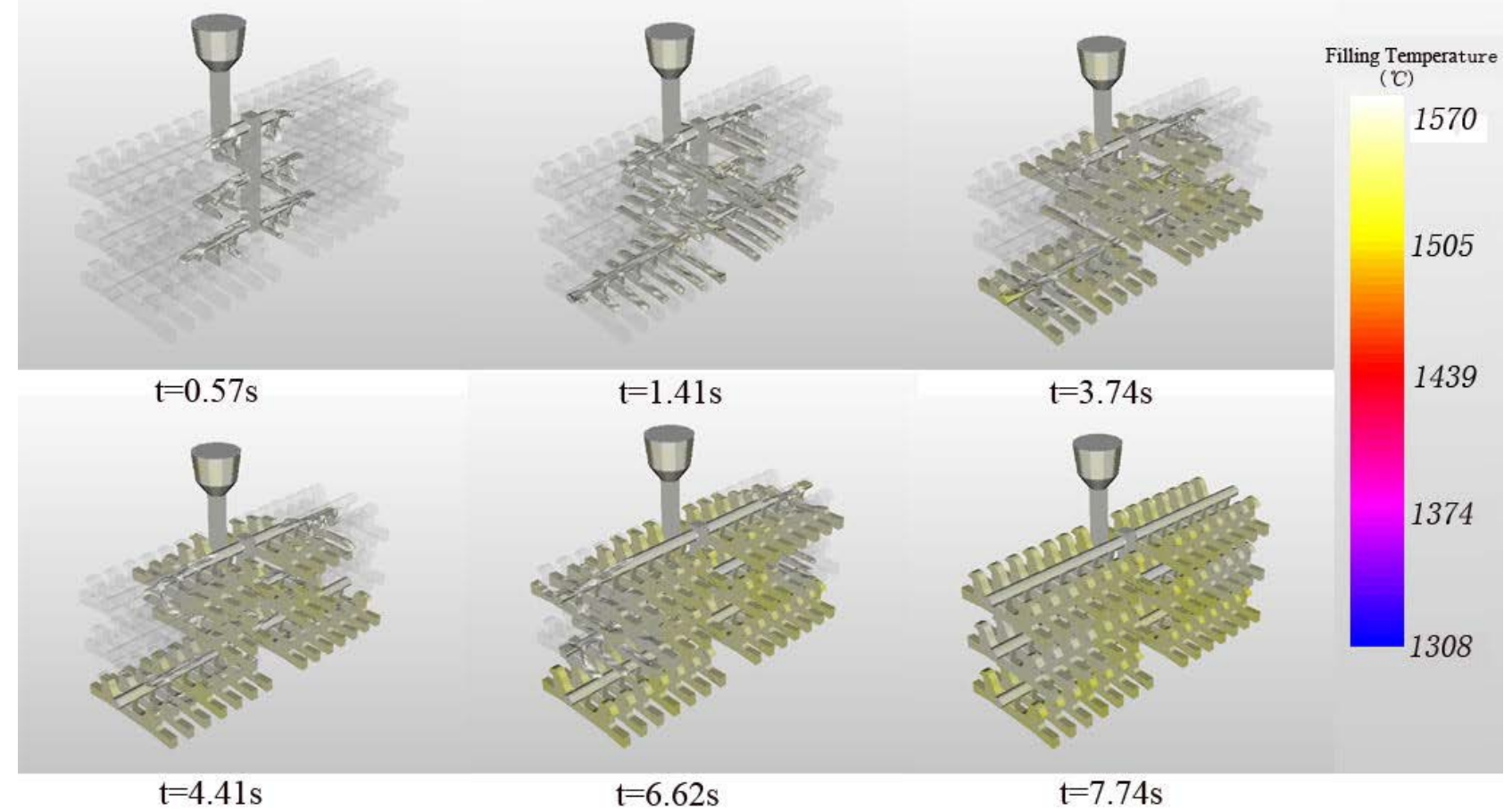

Figure 2. The simulation results of mould-filling after different times.

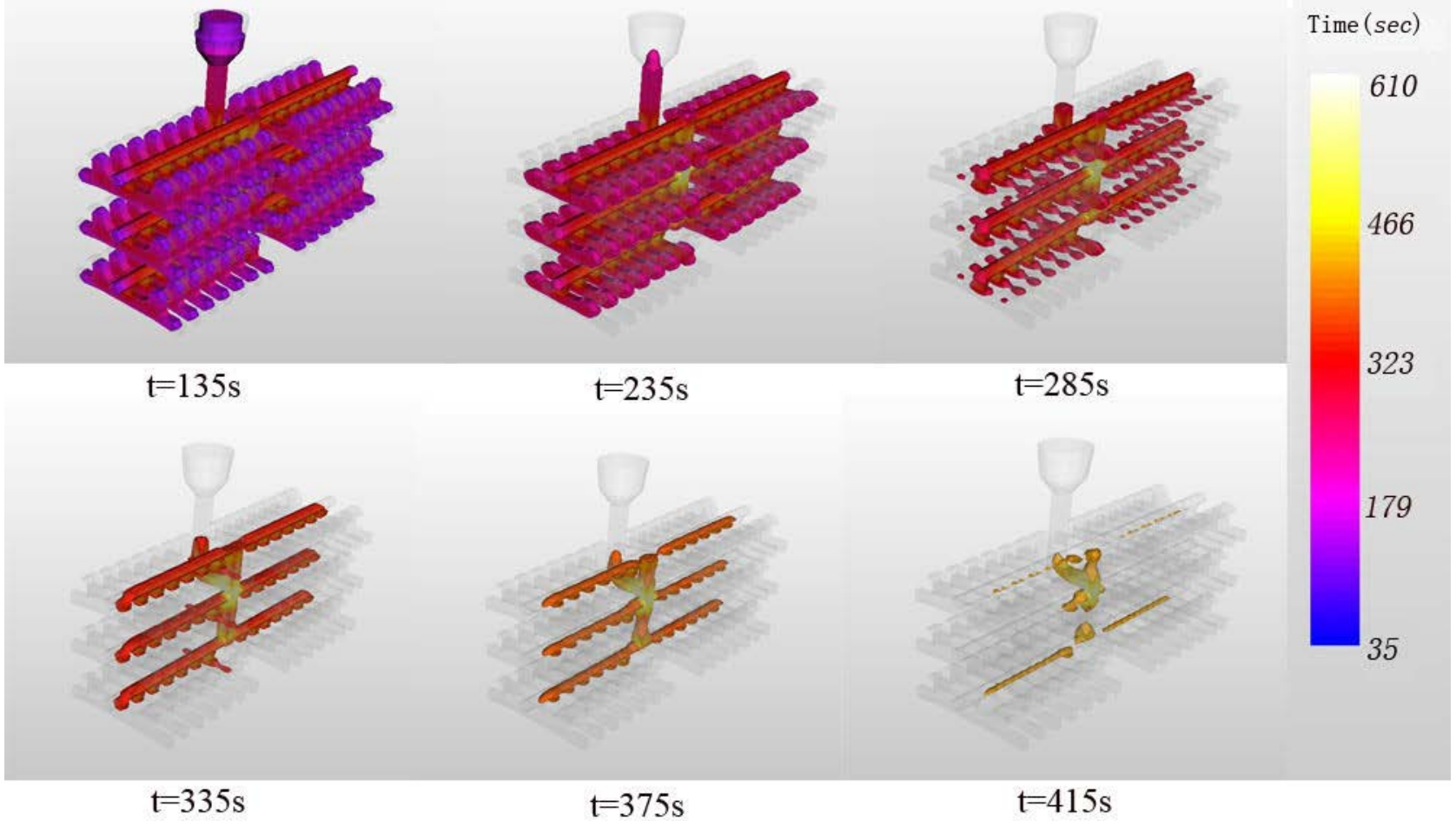

Figure 3. The simulation results of solidification after different times.

The simulation prediction of defects distribution in the castings solidified is completely illustrated in Fig. 4. The transparency in the figure indicates that the metal content is above $95 \%$ and that these parts are deemed as non-defective. It can also be found that large scale of shrinkages exists in the ingrate 
C. Zhiru, X. Lei et al.: The casting process and high...

and sprue cup, while none in the casting. Therefore, the designed casting process is suitable for manufacture of the grate bar. Fig. 5 shows the grate bar produced by the designed casting process. It can be observed that surface smoothness of the casting is excellent.

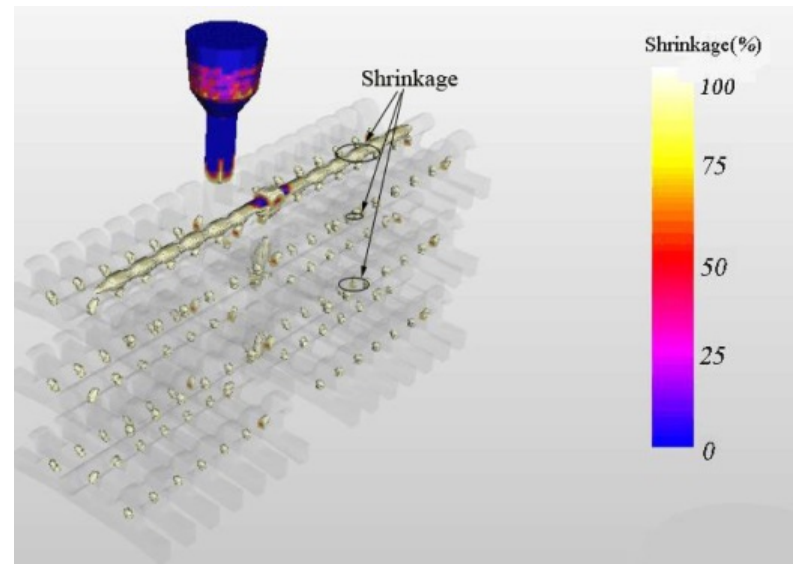

Figure 4. The simulation forecast map of defects in grate bar.
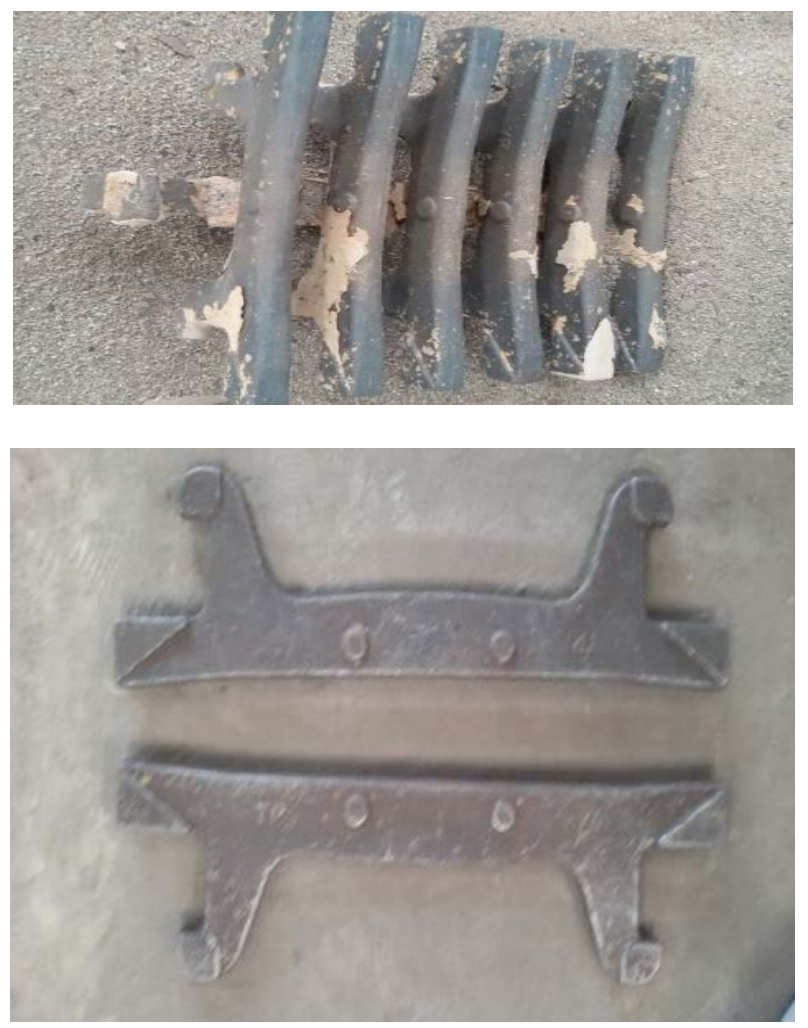

Figure 5. Morphology of grate bar casted by the designed process.

\section{High temperature oxidation resistance of the bar}

\subsection{High temperature oxidation test method}

While sintering machine is working, the grate bars are in the alternating hot and cold working environment. The bar may be heated to the temperature in range of $700^{\circ} \mathrm{C}$ to $900^{\circ} \mathrm{C}$, which requires well high temperature oxidation resistance. Thus, the temperature of high temperature oxidation test was set between $700^{\circ} \mathrm{C}$ and $900^{\circ} \mathrm{C}$.

Before the test, samples cut from the bar were firstly ground into the size of $4 \mathrm{~mm} \times 10 \mathrm{~mm} \times 20$ $\mathrm{mm}$. All samples were cleaned by ultrasonic with acetone solution and anhydrous ethanol orderly. Then these samples were divided into 8 groups, and each group had three samples. Second, the crucible roasted for 1 hour at $150^{\circ} \mathrm{C}$ for holding samples. The crucible and the sample were numbered together and weighted using an analytical balance with the accuracy of $0.0001 \mathrm{~g}$. At last, the crucible containing a sample was put into a furnace to be tested. Four groups were respectively heated to $600^{\circ} \mathrm{C}, 700^{\circ} \mathrm{C}, 800^{\circ} \mathrm{C}$ and $900^{\circ} \mathrm{C}$, inside a high temperature resistance furnace protected by argon gas, while the other four without the protected gas. After being kept for 5 hours, the crucibles were taken out and were air cooled to room temperature. Again the crucibles with the sample were weighted together.

According to the national standard (GB/T 1330391), the oxidation rate would be calculated as the following formula.

$$
K=\frac{m_{l}-m_{o}}{s_{o} \cdot t}
$$

Where $K$ is weight gain on per square meter at per hour, $m_{l}$ is the weight of the crucible containing sample after tested, $m_{0}$ is the weight of that before tested, $S_{o}$ is the superficial area of sample and $t$ is the keeping time at the tested temperature. Based on the test data, average weight gains of the samples on per square meter at per hour are calculated, shown in Table 2. 
Table 2. Average weight gains of the samples tested at different temperatures with or without protected gas

\begin{tabular}{|c|c|c|}
\hline \multirow{4}{*}{$\begin{array}{c}\text { Experimental } \\
\text { conditions }\end{array}$} & $\begin{array}{c}\text { Test } \\
\text { Temperature }\end{array}$ & $\begin{array}{c}\text { Average weight } \\
\text { gain on per square } \\
\text { meter at per hour }\end{array}$ \\
\cline { 2 - 3 } & ${ }^{\circ} \mathrm{C}$ & $\mathrm{g} / \mathrm{m}^{2} \cdot \mathrm{h}$ \\
\hline \multirow{3}{*}{ Non protected } & 600 & 0.67076 \\
\cline { 2 - 3 } & 700 & 0.56127 \\
\cline { 2 - 3 } & 800 & 0.90679 \\
\cline { 2 - 3 } & 900 & 3.45811 \\
\hline \multirow{3}{*}{$\begin{array}{c}\text { Protected by } \\
\text { argon gas }\end{array}$} & 600 & 0.08990 \\
\cline { 2 - 3 } & 700 & 0.07425 \\
\cline { 2 - 3 } & 800 & 0.13708 \\
\hline
\end{tabular}

\subsection{The analysis of high temperature oxidation resistance}

It is obvious to see from Table 2 and Figure 6 that the weight gain on per square meter at per hour is $0.67076 \mathrm{~g}$ after being kept at $600^{\circ} \mathrm{C}$ for $6 \mathrm{~h}$ and cooled to room temperature without argon protection. When the temperature was raised to $700^{\circ} \mathrm{C}$, the oxidation rate is slightly decreased to be $0.56127 \mathrm{~g} / \mathrm{m}^{2} \cdot \mathrm{h}$. When the test temperature reached $800^{\circ} \mathrm{C}$, oxidation rate is $0.90679 \mathrm{~g} / \mathrm{m}^{2} \cdot \mathrm{h}$, which is about $35 \%$ higher than that at $600^{\circ} \mathrm{C}$. The oxidation rate is sharply increased to be $3.45811 \mathrm{~g} / \mathrm{m}^{2} \cdot \mathrm{h}$, about 5 times of that at $600^{\circ} \mathrm{C}$, with raising the test temperature to $900^{\circ} \mathrm{C}$.

At high temperature, iron is easily oxidized on the surface of the sample. And the formation of $\mathrm{FeO}$, $\mathrm{Fe}_{3} \mathrm{O}_{4}$ or $\mathrm{Fe}_{2} \mathrm{O}_{3}$ oxide is related to the temperature. Below the temperature of $560^{\circ} \mathrm{C}$, the oxide film mainly consists of $\mathrm{Fe}_{3} \mathrm{O}_{4}$ and $\mathrm{Fe}_{2} \mathrm{O}_{3}$, which have higher density and small lattice constant. The film can prevent the diffusion of oxygen atoms and then delay the oxidation of iron. When the temperature is over $560^{\circ} \mathrm{C}, \mathrm{FeO}$ layer will be formed under the oxide films of $\mathrm{Fe}_{3} \mathrm{O}_{4}$ and $\mathrm{Fe}_{2} \mathrm{O}_{3}$. $\mathrm{FeO}$ layer has a simple lattice structure, which is the omission solid solution of iron atoms. It is easier for oxygen atoms to diffuse through $\mathrm{FeO}$ layer combining with iron atoms and aggravate iron oxidation [14].

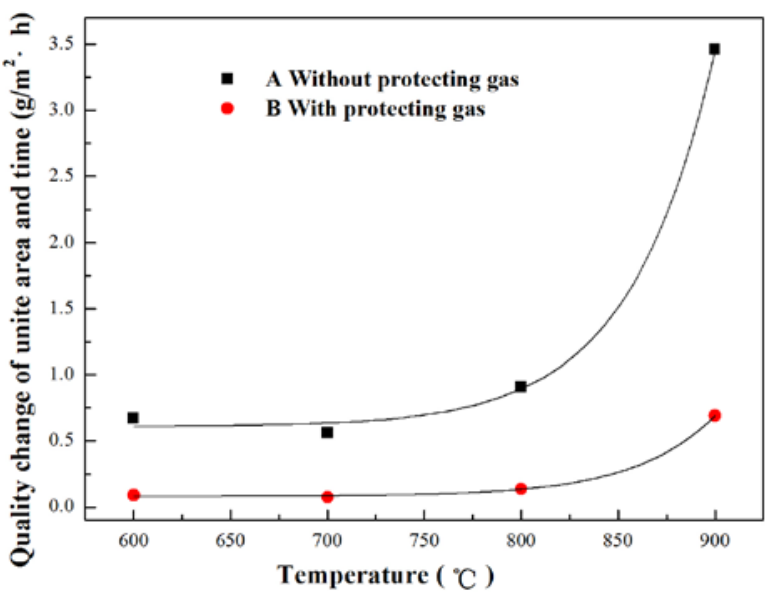

Figure 6. Oxidation rates of the tested samples with or without protection by argon gas under different temperatures.

Moreover, chromium content of the experimental grate bar was very high, $\mathrm{Cr}$ atoms would also combine with oxygen atoms, then $\mathrm{Cr}_{2} \mathrm{O}_{3}$ oxide film formed. $\mathrm{Cr}_{2} \mathrm{O}_{3}$ oxide film firmly combined with the casting and prevented the diffusion of oxygen atoms. Furthermore, $\mathrm{Cr}$ element raised the formation temperature of $\mathrm{FeO}$. As a result, the oxidation resistance temperature was promoted. By the corporate protection of $\mathrm{Fe}_{3} \mathrm{O}_{4}, \mathrm{Fe}_{2} \mathrm{O}_{3}, \mathrm{Cr}_{2} \mathrm{O}_{3}$ films, the sample had well oxidation resistance at temperature in range of $600^{\circ} \mathrm{C}$ to $800^{\circ} \mathrm{C}$, without protected argon gas. The oxidation rate of the sample was delayed to be only about 0.56127 $\mathrm{g} / \mathrm{m}^{2} \cdot \mathrm{h}$ to $0.90679 \mathrm{~g} / \mathrm{m}^{2} \cdot \mathrm{h}$, as shown in Fig. 6 .

SEM was used to investigate the oxide film formed at $800^{\circ} \mathrm{C}$, shown in Fig. 7. It can be observed that the content of $\mathrm{Cr}$ sharply increases in the area where the scanning distance is $1.6 \mu \mathrm{m}$, while the content of $\mathrm{Fe}$ is less. When the scanning distance reaches about $7.2 \mu \mathrm{m}$, the content of $\mathrm{Cr}$ decreases rapidly, while that of Fe increases sharply. It is obvious that a $5.6 \mu \mathrm{m}$-thick oxidation layer exited between resin and matrix of the sample. Variations of the concentrations of $\mathrm{Cr}, \mathrm{Fe}$ and $\mathrm{O}$ indicate that the outer and the inner layer of the oxide film were consisted of equivalent amount of iron oxide and chromium oxide. However, in the middle layer, the film was mainly chromium oxide, considered as $\mathrm{Cr}_{2} \mathrm{O}_{3}$, while that of the iron oxide was few. It is thought that this kind of middle layer of the oxide film is conductive to delay the diffusion of oxygen and improve high temperature oxidation resistance of the sample. 

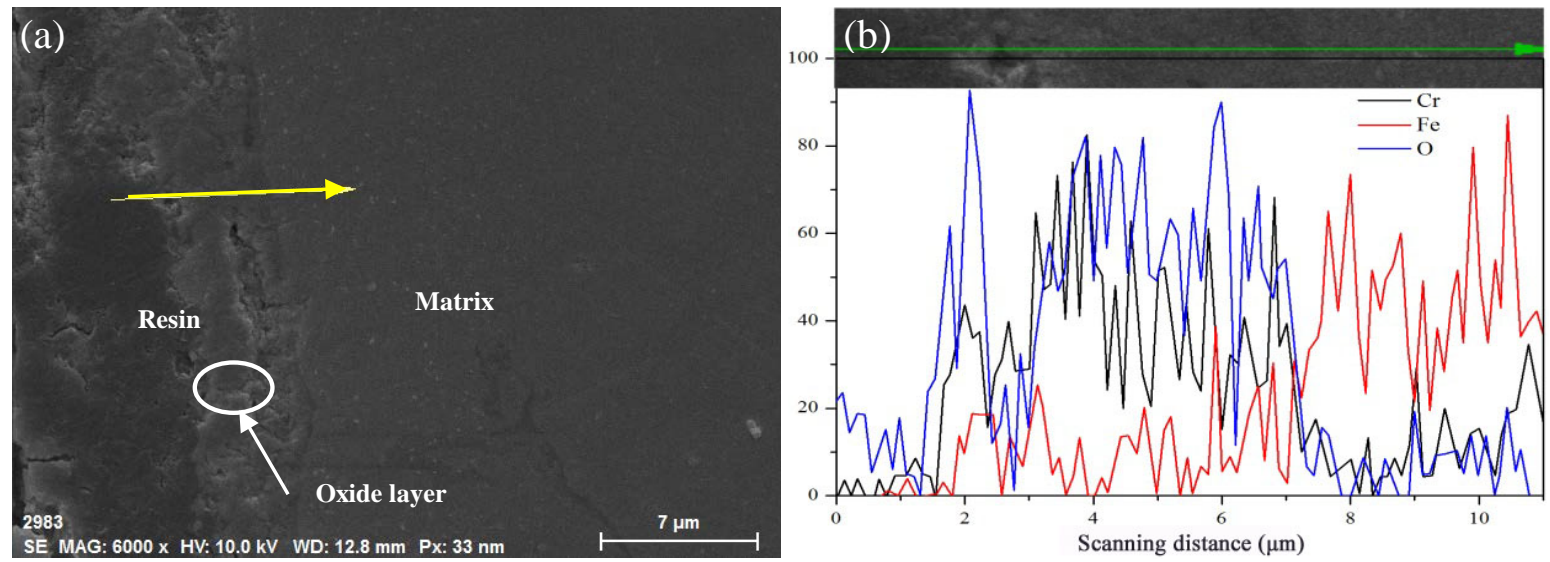

Figure 7. Linear SEM-EDS scanning of the oxide layer formed on the sample tested at $800{ }^{\circ} \mathrm{C}$ without protected gas.

The result of Linear SEM-EDS scanning of the oxide film formed at $900^{\circ} \mathrm{C}$ is shown in Fig. 8. It can be seen that the thickness of the oxide film is about $11.5 \mu \mathrm{m}$ (scanning distance from $1.5 \mu \mathrm{m}$ to 13 $\mu \mathrm{m})$, much thicker than that formed at $800^{\circ} \mathrm{C}$. It has also been found that the concentration of iron is about equal to that of chromium in the majority of the oxide film, which reduces the compactness. In the inner layer close to the matrix, the concentration of iron is higher than that of chromium, which is considered to be mainly consist of $\mathrm{FeO}$. This kind of oxide film can not prevent the diffusion of oxygen, leading to severe oxidation of the bar. This phenomenon is analyzed to be caused by dissolution of chromium. Since chromium is a strong carbide

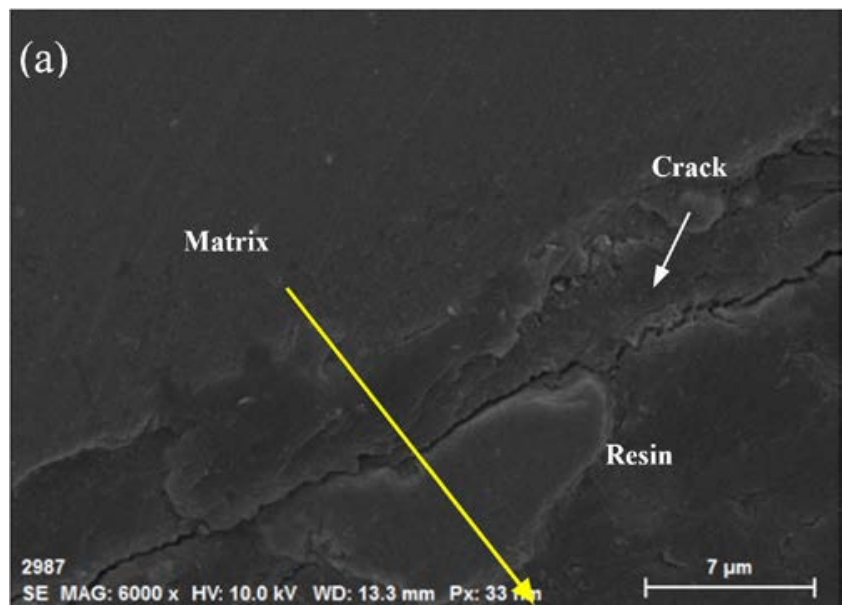

forming element, it will dissolve in cementite to form alloy cementite with the sample heated at $900^{\circ} \mathrm{C}$. As a result, $\mathrm{Cr}_{2} \mathrm{O}_{3}$ membrane reduced and broke gradually, then oxygen atoms diffused inside, leading to rapid oxidation and consequent significant increase of the weight gain. When oxidation temperature was high, the frequent contact, collision, and friction between the grate bar and sintering material result in the fast growth, abscission, and sprout of oxide film on the surface of the grate bar. At last, the grate bar breaks down. In order to improve the service life of the grate bar, working temperature must be controlled strictly.

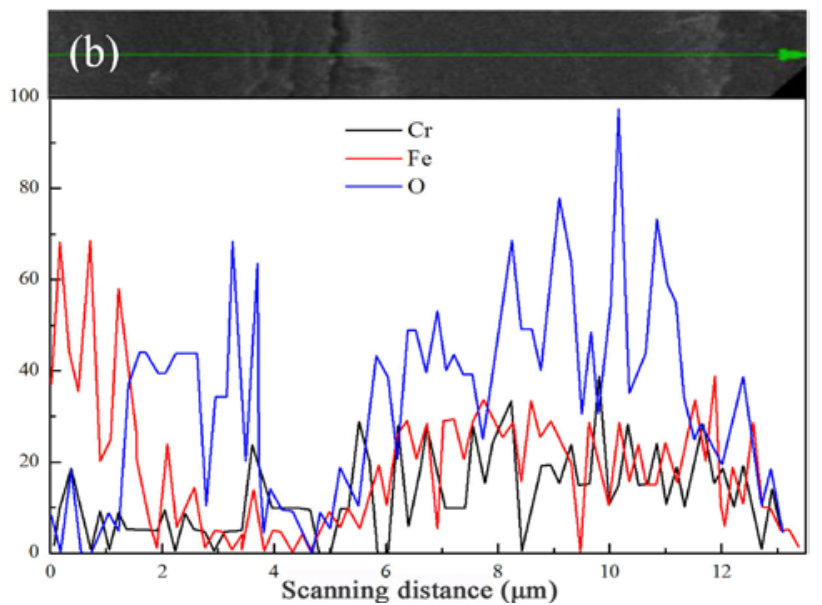

Figure 8. Linear SEM-EDS scanning of the oxide layer formed on the sample tested at $900{ }^{\circ} \mathrm{C}$ protected by argon gas. 
In the test, it has also been found that the weight gain is lower by near an order of magnitude on the sample protected by argon gas, compared with the non-protected, shown in Fig. 6(b). Only when the test temperature was raised to $800^{\circ} \mathrm{C}$, the oxidation rate increased gradually. The oxidation rate at $900^{\circ} \mathrm{C}$ increased substantially, similar to that at air atmosphere, and reached 0.69240 $\mathrm{g} / \mathrm{m}^{2} \bullet \mathrm{h}$. Fig. 9 is the linear SEM-EDS scanning of the oxide layer cross section under $900^{\circ} \mathrm{C}$ with

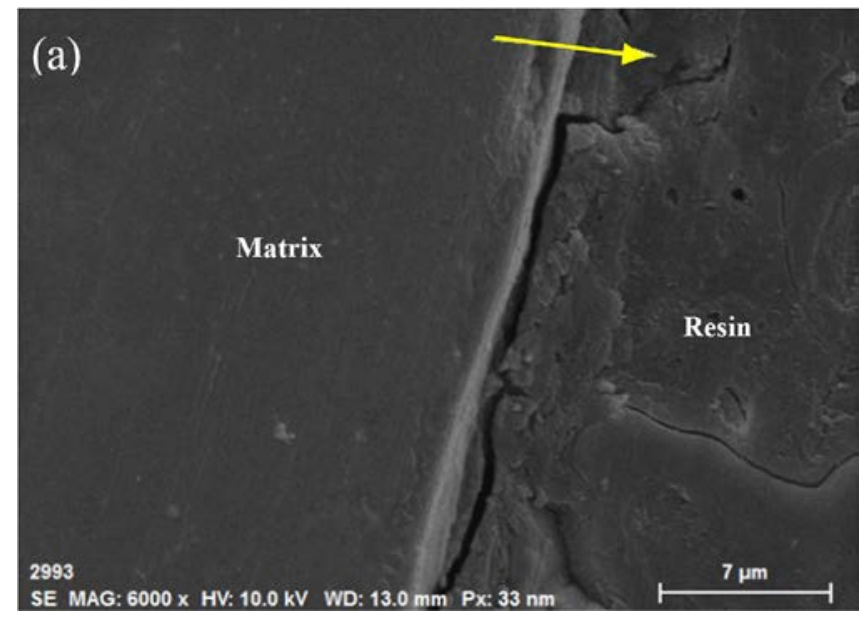

argon gas. From the line scanning, about $1.8 \mu \mathrm{m}$ thick oxide film containing much $\mathrm{Cr}$ can be observed. The variations of concentrations $\mathrm{Fe}, \mathrm{Cr}$ and $\mathrm{O}$ in the oxide film are similar as that in the film, formed at $900^{\circ} \mathrm{C}$ without the protected gas. Hence, it is apparent that the oxidation mainly occurred in heating and insulation process, while rarely existed in the cooling. The oxidation is notably affected by temperature and the consequent constitute of the oxide film.

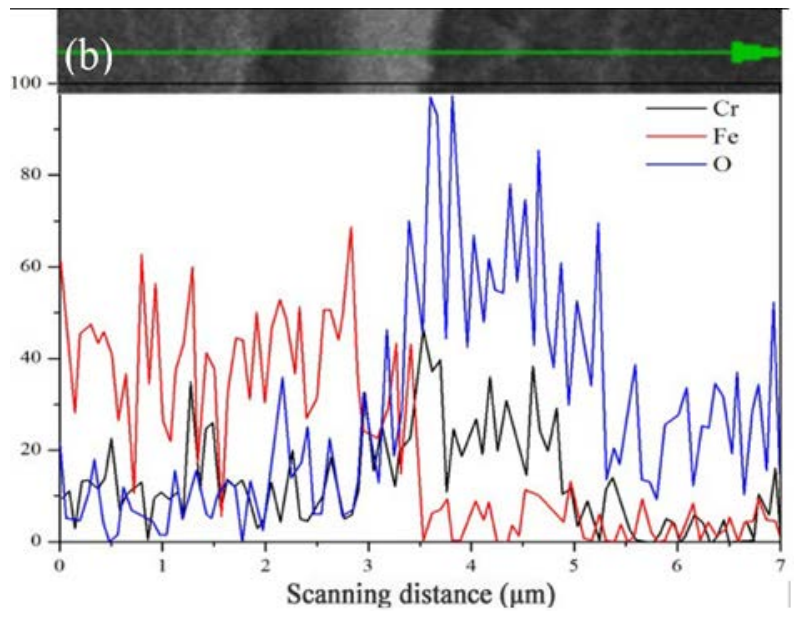

Figure 9. Linear SEM-EDS scanning of the oxide layer formed on the sample tested at $900{ }^{\circ} \mathrm{C}$ without protected gas.

\section{Conclusion}

A kind of high chromium cast iron was designed and used for grate bar. In order to reduce or eliminate the cast defects, casting process was designed and simulated. High temperature oxidation resistance of the manufactured bar was also investigated according to the working conditions. The main results are shown as follows:

(1) Chemical composition of the grate bar was shown as follow: 1.6\% 2.4\% carbon, 15\% 18\% chromium, $1.8 \% \sim 2.2 \%$ silicon, $\leq 1.0 \%$ manganese, $\leq 0.01$ phosphorus, $\leq 0.05$ sulphur.

(2) The simulation results show that the casting process parameters and pouring system size can satisfy the requirement of a high chromium grate bar, with the ingrate diameter of $40 \mathrm{~mm}$, the middle sprue, runner and sprue size of $40 \mathrm{~mm} \times 40 \mathrm{~mm}$. Defects of shrinkage cavity and porosity can be eliminated in the grate bar casting.

(3) The high temperature oxidation test shows that weigh gain increases slowly with the temperature increase from $600^{\circ} \mathrm{C}$ to $800^{\circ} \mathrm{C}$, while increases sharply at temperature of $900^{\circ} \mathrm{C}$. Oxidation mainly occurs in heating and insulation process and is notably affected by temperature and the consequent constitute of the oxide film.

\section{Acknowledgments}

The work has been performed by the financial support of the National Natural Science Foundation of China (Grant No. 51401077) and Key research Program for Higher Education Henan Province (Grant No. 16A450002). In addition, thanks are given to the faculty of the Materials Science and Engineering of Henan Polytechnic University.

\section{References}

[1] Sarkar, P. P., Dhua, S.K., Dhara, S., DE, S.K.: Metallurgical investigation into the failure of an iron ore sintering car pallet, Engineering Failure Analysis, 63(2016), 31-42.

[2] Li, S., Zhang, Y.P, Lei, H.: Development and foreground of domestic grate bars used in 
sinter sachines, Hot Working Technology, 37(2008), 9, 100-103.

[3] Fish, S., Booth, J.C., Kubiak, S.T.: Design and subsystem development of a high temperature selective laser sintering machine for enhanced process monitoring and control, Additive Manufacturing, 5(2015), 60-67.

[4] Song, C.Y., Zhang, W., Yang, L., Gui, Y.L.: Present application status and prospect of the cast iron materials for sintering machine trolley, Mater Rev: Res, 26(2012), 402-404.

[5] Gui, Y.L., Liu, J., Wang, M.N., Song, C.Y.: Wear and Oxidation Resistance of High Chromium Cast Iron for Sintering Grids, Foundry Technology, 37(2016), 4, 619-621.

[6] Xia, Q., Yang, D.X.: Research on oxidationresistant property of high chromium iron at high temperature, Foundry, 55(2006), 6, 629635.

[7] Ramírez-Ramírez, J.H., Colás, R., GarzaMontes-de-Oca, N.F.: High temperature oxidation of a work roll grade high-chromium white cast iron, Journal of Iron and Steel Research, International, 20(2013), 10, 122-129.
[8] Efremenko, V. G., Chabak, Yu. G., Lekatou, A. et al.: High-Temperature Oxidation and Decarburization of 14.55 wt pct Cr-Cast Iron in Dry Air Atmosphere, Metallurgical and Materials Transactions A, 47(2016), 2, 15291543.

[9] Zhang, A.F., Xing, J.D., Lu, W.H.: Oxidation behavior of high chromium cast iron, Acta Metallurgica Sinica, 29(1993), 6, 263-268.

[10] Liu, H.H.: The Effects of Cryogenic Treatment on Hardening Behavior and Abrasion Resistance of High Chromium Cast Irons Subjected to sub-critical treatment, Sichuan University, 2005.

[11] Zhang, D.M.: Application of numerical simulation in lost foam casting process, Foundry Technology, 36(2015), 1, 245-247.

[12] Li, C.Y., Huang, S., Zhang, Y., Mi, G.F.: Process design and numerical simulation of S60 piston iron casting, Hot Working Technology, 44(2015), 5, 69-71.

[13] Mi, G.F., Li, C.Y., G, Z.: Application of Numerical Simulation on Cast-steel Toothed Plate, Engineering Review, 34(2014), 1, 1-6.

[14] Cui, Z.Q., Liu, B.X.: Metallurgy and Heat Treatment Theory, Third edition, Harbin Institute of Technology Press, Harbin, 2007. 